\title{
The role of innovation in the analysis of abuse of dominance in digital markets: The analysis of chosen practices of Google Search
}

\author{
Beata Mäihäniemi*
}

\begin{abstract}
Competition investigations in digital markets focus increasingly on future markets, and incentives to invest and innovate play here a larger role than in traditional "brick and mortar" industries. The article analyses the role of innovation in cases of abuse of dominance in digital markets on two levels. The first level involves the strength of incentives to invest and innovate of a digital monopolist - would he have less or more incentives to innovate and prefer to resort to practices that foreclose his competitors or leverage his market power to adjacent markets to keep its dominant position on the market? The second level identifies concrete phases of the competition analysis in which innovation considerations are contemplated in digital markets, such as objective justifications or assessing the effect of the practice on consumer welfare. The analysis of the role of innovation in the assessment of alleged anticompetitive abuses is conducted on the example of two concerns expressed by the EC in recent investigations into practices of Google Search, namely (1) search bias and (2) restrictions on portability of advertising data to competing advertising platforms.
\end{abstract}

KEYWORDS: innovation, Google, digital markets, abuse of dominance, incentives to invest and innovate, search bias, restrictions on portability, Schumpeter, Arrow

\section{Introduction}

Innovation is a common concern in digital markets, it is also an inevitable part of every digital business's life. Companies in digital markets need to innovate to survive, can therefore a company be condemned based on competition law for simply trying to avoid being challenged by some disruptive innovation? Incentives to invest and innovate became a more urgent

\footnotetext{
* $\mathrm{PhD}$ student in competition law at the University of Helsinki, beata.maihaniemi@helsinki.fi.
} 
concern in digital markets than prices. However, they do not seem to be taken sufficiently into account by the EU competition law. In particular, in cases involving abuse of dominance, a dominant company could possibly defend itself claiming that instead of being involved in an exclusionary practice, it is in fact trying to compete on merits by innovating as to improve its products or services. Nevertheless, a dominant company could be also put under the antitrust scrutiny if it is found that the practice in question affects innovation in a negative way. The last situation is still ambiguous as the current state of competition law requires that the practice which has a negative effect on consumers by depriving them of new or improved products or limits their choice, should lead to anticompetitive foreclosure.

This article aims at analysing the role of innovation in cases of abuse of dominance in digital markets on two levels.

The first level of the analysis focuses on the strength of incentives to invest and innovate of a digital monopolist. Would such a monopolist have less incentives to innovate and prefer to resort to practices that foreclose his competitors or leverage his market power to adjacent markets in order to keep his dominant position on the market? Or is he forced to innovate since he is constantly challenged by its competitors who may, any time in the future, challenge and destroy the temporary digital monopoly? Several theories on innovation could help answering this question, however, this article focuses on two particular approaches. Firstly, it takes into account Schumpeter's claims that larger firms will tend to innovate more than small ones as well as Arrow's findings that product market competition actually encourages more innovation. Does this discussion make sense in digital markets? Is digital monopoly indeed that strong and does it have more resources to support its research and development than smaller firms? The answer to this question may lay in the distinction between different kinds of innovation and their different effects on welfare.

The second level of the analysis focuses on the concrete phases of the competition analysis in which innovation considerations are taken into account in digital markets. It seems that innovation considerations are of the highest value in objective (especially business) justifications, e.g. a monopolist can refuse sharing an input such as IPR or trade secret to prevent free riding on its innovation. However, innovation also plays an important role in the assessment of the effect of the practice on consumer welfare, e.g. where the Commission notes that the practice in question will lessen incentives to innovate of the rivals in the result of which consumers 
will be deprived of new and improved products or wider consumer choice. Consequently, innovation considerations can be used both as a defence of dominant undertaking and as the reason for antitrust intervention based on dynamic inefficiency that derives from an anticompetitive conduct. It is unclear which of these are stronger and why and this depends largely on the circumstances of an individual case and should be based on the assessment of effects of the practice in question.

This dual purpose of innovation considerations is especially visible in Google Search investigations. Google, just like IBM and Microsoft, is an example of a new technology case where a monopolist does not only threaten monopoly power but also harms rivals and competition. ${ }^{1}$ Consequently, Google is the most recent example of antitrust investigations, where competition agencies struggle with the application of conventional tools of competition law to the environment of new technology and perhaps do not take sufficiently into account innovation considerations.

The analysis of the role of innovation in the assessment of alleged anticompetitive abuses is conducted on the example of two concerns expressed by the European Commission in recent investigations into practices of Google Search. These are (1) contractual restrictions on portability of advertising data to competing advertising platforms and (2) search bias. These two practices are ambiguous as they are based on the "mixed motives" of the dominant undertaking and one can argue that they are either product improvements or anticompetitive practices. What is more, both of these practices concern some kind of refusal to access to or misappropriation of information, which, due to specific characteristics of information as an economic good, further complicate the analysis.

This article is therefore not only aiming at the identification of the relevance of innovation considerations for abuses of dominance that arise in digital markets in general. It also strives to predict the outcome of one of the most-followed EC competition investigations, the result of which is still unknown. The European Commission has not, until Google Search case, analysed an issue which was so deeply rooted in the Internet ${ }^{2}$, and we can observe concerns that digital monopolies may lead to the situation

\footnotetext{
${ }^{1}$ Michael A. Carrier, Innovation for the $21^{\text {st }}$ Century, Harnessing the Power of Intellectual Property and Antitrust Law (New York: Oxford University Press, 2009), 1.

${ }^{2}$ Alexander Italianer, "Competition Policy in the Digital Age", 47 Innsbruck Symposium - Real sector economy and the Internet - digital interconnection as an issue for competition policy, 16, (2014), http:// ec.europa.eu/competition/speeches/text/sp2014_01_en.pdf.
} 
of "replay of the domination of monopolistic trusts in the late nineteenth century" ${ }^{3}$ and have disastrous consequences such as entrenchment of these monopolies to other markets ${ }^{4}$. This is because digital monopolies may be also artificially preserved and protected from the actions of regulators and politicians. ${ }^{5}$ However, it is unclear whether the "conventional" competition law should be updated to accommodate the digital environment.

\section{Strength of Incentives to Invest and Innovate in Digital Markets}

In this part, we assess which of the two famous theories on innovation will have stronger implications in digital markets - Schumpeter's or Arrow's. We are particularly interested in incentives to invest and innovate of an online platform, such as Google. "Online platforms" include companies such as search engines, social media, e-commerce platforms, app stores, and pricecomparison websites, which play a central role in social and economic life. ${ }^{6}$ Moreover, since many of the online platforms also operate as intermediaries and take a form of two-/multi-sided markets, the conventional methods of market power analysis are insufficient to address problems arising in such an environment. ${ }^{7}$

Two-/multi-sided platforms "enable direct interactions between two or more distinct sides"8 and "each side is affiliated with the platform". "These sides are distinct but in fact interdependent. ${ }^{10}$ Each side benefits directly when more members on the other side join the platform. ${ }^{11}$ In two-sided

\footnotetext{
${ }^{3}$ Frank Pasquale, "Paradoxes of Digital Antitrust Why the FTC Failed to Explain Its Inaction on Search Bias", Harvard Journal of Law \& Technology Occasional Paper Series (2013): 19, http://jolt.law. harvard.edu/antitrust/articles/Pasquale.pdf.

${ }^{4}$ See Tim Wu, The Master Switch. The Rise and Fall of Information Intermediaries (London: Atlantic Books, 2010).

${ }^{5}$ Frank Pasquale, op. cit.: 19.

${ }^{6}$ European Commission, A Digital Single Market Strategy for Europe, Communication to the European Parliament, the Council, the European Economic and Social Committee and the Committee of the Regions, COM (2015) 192 final.

${ }^{7}$ Monopolkommission, Competition Policy: The challenge of digital markets. Special Report by the Monopolies Commission Pursuant to Section 44(1) (4) of the Act against Restraints on Competition, (2015), 1, http://www.monopolkommission.de/images/PDF/SG/SG68/S68_summary.pdf.

${ }^{8}$ Andrei Hagiu and Julian Wright, "Multi-Sided Platforms", International Journal of Industrial Organization 43 (2015): 163.

${ }^{9}$ Ibid.: 163.

${ }^{10}$ Dennis Carlton and Jeffrey Perloff, Modern Industrial Organization (New York: Harper Collins, 2003), 392.

${ }^{11}$ Martin Peitz and Joel Waldfoegel, eds., The Oxford Handbook of The Digital Economy (New York: Oxford University Press, 2012), 60-61. See also e.g., David Bardey et al., "Competition in Two-Sided
} 
markets, one side is usually offered to consumers for free (e.g. access to a search engine) and the other side is offered by numeration (e.g. advertisement of a company in the search results). ${ }^{12}$

When one customer takes measures which have a positive effect on the other customer, the so-called network effects arise. ${ }^{13}$ Network effects can be direct - the more users join the network the more valuable it becomes to its users overall, or indirect, which derive from components that are available as an addition to the main product or service. Network effects, if pronounced, can lead to "tipping" of the incumbent's market power towards the monopoly, competition in such a market is then "for the market", instead of "in the market". ${ }^{14}$ What is more, due to these network effects incumbent's products are usually also advantaged and can only be challenged by entrants that are able to offer innovative products which the incumbent cannot beat with his prices. ${ }^{15}$

Due to the fact that in such markets competition occurs more in future markets than in current ones, competitors' incentives to invest and innovate as well as the notion of potential competition gain an increased importance. The discussion, Schumpeter v. Arrow, although unresolved and widely commented on is still very useful as it sheds a light on different factors that need to be considered when analysing an environment in which innovation may arise. This discussion should be continued as to new technology markets, but it will always be a discussion "in progress". Most of the discussion focuses on situations where information is protected by IPR, however e.g. trade secrets could be taken into account as well.

According to Schumpeter, a monopolist has higher incentives and also funds to innovate than a small firm. ${ }^{16}$ Moreover, what keeps the monopoly going are "new consumers' goods, the new methods of production or transportation, the new markets, the new forms of industrial organization that

Markets with Common Network Externalities", Review of Industrial Organisation 44, 327-345; or Marc Rysman, “The Economics of Two-Sided Markets”, Journal of Economic Perspectives 23, 3 (2009), 125-143.

${ }^{12}$ For more detailed insight into two-sided markets see Jean-Charles Rochet and Jean Tirole, "TwoSided Markets: A Progress Report", The RAND Journal of Economics 37, 3 (2006), 645-667.

${ }^{13}$ Martin Peitz and Joel Waldfoegel, eds., op. cit., 332.

${ }^{14}$ Gregory J. Werden, "Network Effects and Conditions of Entry: Lessons from the Microsoft Case", Antitrust Law Journal 69, 1 (2001): 91.

${ }^{15}$ Ibid.: 92.

${ }^{16}$, Joseph A. Schumpeter, Capitalism, Socialism and Democracy (London: Routledge, 1942), 82-85. 
capitalist enterprise creates". ${ }^{17}$ For example, Google is investing in its own vertical search engines. Nevertheless, as Schumpeter's thesis is applicable to product not technology markets, it does not consider complements, and this significantly narrows the choice of substitution. This is problematic as innovation in fact enhances the value of complements. ${ }^{18}$ Not taking complements into account would narrow the choice of substitutes and would be inacceptable in new technology markets. This seems to be a major flaw of the Schumpeterian approach.

What is more, as the idea of "innovative efficiencies" assumes that producers are challenged by their rivals to continuously innovate and lower the cost of producing their technology, ${ }^{19}$ and the same seems to hold in dynamic markets, it may make a difference which of the kinds of technological innovation will be of highest interest in digital markets - sustaining or disruptive? Sustaining technological innovation is one that offers demanding, high-end consumers better performance, which can be done by e.g. yearly incremental improvements. What is more, battles to offer sustaining innovation are usually won by incumbents as they have resources to win these. ${ }^{20}$ On the contrary, disruptive innovation introduces products and services that revolutionise the direction of the market. These are usually simpler, more convenient and less expensive and therefore attract new or less-demanding consumers. ${ }^{21}$ Battles to offer disrupting innovation are usually won by entrants. ${ }^{22}$

Nevertheless, investing in sustaining innovations does not denote immunity from disruptive ones. ${ }^{23}$ Therefore, the monopolist will do anything to stop rivals from dethroning him. This has been already recognised by Schumpeter, ${ }^{24}$ who introduced the idea of "creative destruction" where new

\footnotetext{
${ }^{17} \mathrm{Ibid} ., 82-83$.

${ }^{18}$ Gregory Sidak and David J. Teece, "Dynamic Competition in Antitrust Law", Journal of Competition Law and Economics 5, 4 (2009): 581.

${ }^{19}$ Steven Anderman and Hedvig Schmidt, EU Competition Law and Intellectual Property Rights. The Regulation of Innovation (Oxford: Oxford University Press, 2011), 14.

${ }^{20}$ Clayton M. Christensen and Michael E. Raynor, The Innovator's Solution: Creating and Sustaining Successful Growth (Boston, Massachusetts: Harvard Business Review Press, 2013), 46.

${ }^{21}$ Ibid., 46.

${ }^{22}$ Ibid., 44.

${ }^{23}$ Alexandre De Streel and Pierre Larouche, "Disruptive Innovation and Competition Policy Enforcement" Organisation for Economic Co-Operation and Development, Global Forum for Competition, Session III, 3 DAF/COMP/GF (2015): 7, https://papers.ssrn.com/sol3/papers. cfm?abstract_id $=2678890$.

${ }^{24}$ Joseph A. Schumpeter, Capitalism, Socialism and Democracy (London: Routledge, 1942).
} 
technologies repeatedly displace older ones which leads to higher economic growth than the ordinary forces of price competition. ${ }^{25}$ "Creative destruction" therefore "incessantly revolutionises the economic structure from within, incessantly destroying the old one, incessantly creating a new on".26 In the process of "creative destruction" incumbent tries to resist new forms of innovation which affect the nature of competition. However, even these newly successful firms, that creatively destruct, will eventually be replaced as this cycle is indefinite. ${ }^{27}$ Therefore, according to Schumpeter, technological innovation occurs in waves by different technologies, as he calls it - "perennial gales of creative destruction". Antitrust law should aim at promoting creative destruction by reducing barriers to entry. ${ }^{28}$ To protect his position, digital monopoly may become involved in the so-called "defensive leveraging." ${ }^{29}$ He may be keeping its position in the market to drive competitors out of it and impede innovation so that new products and services could not enter the market.

Arrow claims that it is more likely that innovation, especially the disruptive one, would come from small outsiders that could come up with disruptive innovations. ${ }^{30}$ Therefore, the incentive to invent is less under monopolistic than under competitive conditions. ${ }^{31}$ Rivalry, will offer consumers new services and better terms. ${ }^{32}$ The problem that arises here is that for disruptive innovation to succeed, it must draw to itself consumers that are either new or unserved by the disrupted product or service or that are drawn away from that product or service in the first place. This may be difficult to achieve where consumers become locked-in into existing product or standard.

\footnotetext{
${ }^{25}$ Hebert J. Hovenkamp, “Competition for Innovation”, University of Iowa, Legal Studies Research Paper 13, 26 (2013): 4-5, https://papers.ssrn.com/sol3/papers.cfm?abstract-id=2008953.

${ }^{26}$ Joseph A. Schumpeter, op. cit., 97-98.

${ }^{27} \mathrm{Ibid}$., after Spencer Weber Waller and Matthew Sag, "Promoting Innovation", Iowa Law Review 100 (2015), 2226.

${ }^{28}$ Ibid., 2229.

${ }^{29}$ Tim Wu, op. cit., 25.

${ }^{30}$ Kenneth J. Arrow, "Economic Welfare and the Allocation of Resources for Invention", in The Rate and Direction of Inventive Activity: Economic and Social Factors, ed. Universities-National Bureau Committee for Economic Research, Committee on Economic Growth of the Social Science Research Council (Princeton: Princeton University Press, 1962), 609.

${ }^{31}$ Ibid., 619.

${ }^{32}$ Howard Shelanski, "Information, Innovation, and Competition Policy for the Internet", University of Pennsylvania Law Review 161, 1 (2013): 1668.
} 
For example, due to Google's popularity, or also because some of the users believe that other horizontal search engines do not appeal to them, some users may be reluctant to switch to alternative search engines. This can be partly explained by status quo bias, which denotes that "doing nothing or maintaining one's current or previous decision is almost always a possibility". ${ }^{3}$ Therefore, although it seems that in new technology markets barriers to entry are either non-existent or very weak, consumers may prefer to stick to the "old" standards instead of incurring significant learning costs. This is mostly done for convenience reasons. Status quo bias therefore explains why consumers prefer to stick with the default option, even though superior alternatives can be easily accessed. ${ }^{34}$ What is more, a new network may be killed before it is even started as consumers who join the new network early may fear being stranded if everyone else chooses a different network. Therefore, the new network should convince its new customers that it will be successful, this can be done e.g. by offering a better price, etc. ${ }^{35}$ To draw customers to itself a newcomer should offer them a better deal. Even though switching costs and network benefits may be aiming at preventing new services or products from succeeding, it may still be more attractive to consumers than the older one. However, an incumbent, to protect its dominant position, may invest in improvements that a rival has, which will strengthen its dominant position even further. ${ }^{36}$

What is more, in digital markets, even though the new entrant may be offering a better product or service, it will still lack the scale of this trial-anderror effects. They denote a situation in which search results are adapted to previous searches of consumers as well as their preferences. Trial-andlearning effects are then considered as a main competitive disadvantage in attracting consumers and advertisers. ${ }^{37}$ The trial-and-error learning effects have to be however conducted on the sufficient scale. These effects may give Google an insurmountable advantage over its rivals, however, this does not denote that they could not be achieved by newcomers as regards a disruptive product or service.

\footnotetext{
${ }^{33}$ Joseph A. Schumpeter, op. cit., 82-83.

${ }^{34}$ Maurice E. Stucke, "Behavioural Antitrust and Monopolization", Journal of Competition Law and Economics 8, 3 (2012): 552. More on behavioural antitrust in Amanda P. Reeves and Maurice E. Stucke, "Behavioural Antitrust", Indiana Law Journal 86 (2011): 1527-1586.

${ }^{35}$ Suzanne Scotchmer, Innovation and Incentives (Cambridge - Massachusetts: The MIT Press, 2004), 295.

${ }^{36}$ Ibid., 296.

${ }^{37}$ Maurice E. Stucke, op. cit.: 555.
} 
The so-called breakthrough that is disruptive innovation does not generate wealth to the same extent as sustaining, follow-on innovations do. This is because follow-on innovations in fact adapt the breakthrough innovation to accommodate social needs. They bring more income and create job opportunities. This wealth cannot be achieved without accessing the knowledge about breakthrough innovation by creators' competitors. ${ }^{38}$ Therefore, the fact that a company is an incumbent with a large market power does not denote that it will innovate as innovation is not connected to the firm size. ${ }^{39}$ What is more, the opposite is also true as a small company may be able to find funding for its disruptive innovation. This can be found from inside sources, such as efficient sale of products, but also outside ones. For example, capital markets could provide financing for future projects. Moreover, some product development goals can be achieved by collaborative organizational agreements, such as joint ventures or co-production and co-marketing agreements. ${ }^{40}$

To sum up, as it is not easy for small companies to take over the market with disruptive innovation, yet, it is also not entirely impossible, especially in digital markets which often do not require expensive pre-investments and long prior phases of Research and Development. Competition policy has therefore a larger role for disruptive innovation, as due to its radical nature, it has a larger impact on consumer welfare and existential threat to rivals. That is incumbents have higher incentives to block disruptive innovation..$^{41}$ What is more, nowadays such disruptive innovation can also be undergone "on the cheap" and they may enjoy network effects which can lead to market tipping. ${ }^{42}$ Disruptors are emerging players who offer products that are cheaper and more convenient, who offer disruptive products that serve new customers who were previously not given enough attention to. ${ }^{43}$ It is still ambiguous why some companies are more capable of engaging in disruptive innovation than others. ${ }^{44}$

\footnotetext{
${ }^{38}$ Björn Lundqvist, Standardization under EU Competition Rules and US Antitrust Laws. The Rise and Limits of Self-Regulation (Cheltenham, UK/Northampton, Massachusetts: Edward Elgar, 2014), 95.

${ }^{39}$ Ibid., 598.

${ }^{40}$ Gregory Sidak and David J. Teece, op. cit.: 590.

${ }^{41}$ Alexandre de Streel and Pierre Larouche, op. cit.: 6.

${ }^{42}$ Ibid.: 3.

${ }^{43}$ Richard Karlgaard, The Soft Edge: Where Great Companies Find Lasting Success (San Francisco: Jossey-Bass, 2014), 7.

${ }^{44}$ Gregory Sidak and David J. Teece, op. cit.: 597.
} 


\section{Phases of Competition Analysis in Which Incentives to Invest and Innovate Can be Taken into Account}

It seems that innovation considerations are of the highest value in objective justifications (especially business justifications), e.g. a monopolist can refuse sharing an input such as IPR or trade secret to prevent free riding on its innovation. However, innovation also plays an important role in the assessment of the effect of the practice on consumer welfare, e.g. where the Commission notes that the practice in question will lessen incentives to innovate of the rivals in the result of which consumers will be deprived of new and improved products or their choice of goods will be limited. Consequently, innovation considerations can be used both as a defence of dominant undertaking and as the reason for antitrust intervention.

\subsection{The Role of Objective Justifications by Digital Monopolies}

The Article 102, unlike 101 TFEU, does not state explicitly that a dominant undertaking could try to justify its allegedly anticompetitive behaviour. ${ }^{45}$ However, the European Commission allows the use of justification, as it had stressed in its Guidance on Article 82 [now 102] ${ }^{46}$ Consequently, although some practices are considered abusive, they may be justified based on objective arguments. In Irish Sugar it has been stressed that

even if the existence of a dominant position does not deprive an undertaking placed in that position of the right to protect its own commercial interests when they are threatened (...), the protection of the commercial position of an undertaking in a dominant position with the characteristics of that of the applicant at the time in question must, at the very least, in order to be lawful, be based on criteria of economic efficiency and consistent with the interests of consumers. In this case, the applicant has not shown that those conditions were fulfilled. ${ }^{47}$

The dominant company introduces objective justification by demonstrating that its conduct is objectively necessary or it produces substantial

\footnotetext{
${ }^{45}$ Tjarda Van Der Vijver, “Objective Justification and Article 102 TFEU”, World Competition 35, 1 (2012): 55 .

${ }^{46}$ European Commission, Guidance on the Commission's Enforcement Priorities in Applying Article 82 of the EC Treaty to Abusive Exclusionary Conduct by Dominant Undertakings, OJ C45/02, 2009.

47 Judgment of 26 November 1998, Irish Sugar plc v Commission, T-228/97, EU:C:1998:569, paragraph 189.
} 
efficiencies which outweigh any anticompetitive effects on consumers. ${ }^{48}$ In this context, the Commission will assess whether the conduct in question is indispensable and proportionate to the goal allegedly pursued by the dominant undertaking. ${ }^{49}$ The conduct may be objectively necessary for health or safety reasons which are related to the nature of the product in question..$^{50}$ This denotes explanations other than efficiencies. It can also take into account technical or commercial requirements relating to the product or service. Moreover, demonstrating that the product is objectively necessary does not require balancing between the negative and positive effects. ${ }^{51}$

Efficiencies should outweigh the negative effect of the practice in question. For example, in the British Airways, ${ }^{52}$ it has been stressed that such efficiencies can only be proved based on the whole of the circumstances of the case. Moreover, the exclusionary effect of the practice can be counterbalanced or outweighed by advantages in terms of efficiency which also benefit the consumer. Where the exclusionary effect has nothing to do with the efficiencies, the practice must be regarded as an abuse..$^{53}$ In Intel, for the conduct to be capable of achieving the legitimate goal, it was required that it had no equally effective alternative in achieving the legitimate goal with a less restrictive or less exclusionary effect and that the conduct was "proportionate". Proportionality denotes that "the legitimate objective pursued by Intel should not be outweighed by the exclusionary effect". ${ }^{4}$

\subsubsection{Objective Justifications for Restrictions on Portability of Online Data}

Google has been accused of restricting the possibility to simultaneously manage campaigns on AdWords and competing online search advertising platforms. In investigations conducted in the US, FTC also pointed out that restrictions on portability of advertising data impaired competition in search advertising, ${ }^{55}$ as well as restricted ability of small businesses to

\footnotetext{
${ }^{48}$ Ibid., paragraph 30.

${ }^{49} \mathrm{Ibid}$., paragraph 28.

${ }^{50} \mathrm{Ibid}$., paragraph 29.

${ }^{51}$ Jonathan Faull and Ali Nikpay, eds., Faull and Nikpay: The EU Law of Competition, $3^{\text {rd }}$ ed. (Oxford: Oxford University Press, 2014), 395.

${ }^{52}$ Judgment of 15 March 2007, British Airways v. Commission, C-95/04, EU:C:2007:166.

${ }^{53} \mathrm{Ibid}$., paragraph 86.

${ }^{54}$ Intel Corporation, Case COMP/37.990, Commission Decision [2009] OJ C227/07, paragraph 1624.

${ }^{55}$ Federal Trade Commission, Google Agrees to Change Its Business Practices to Resolve FTC Competition Concerns in the Markets for Devices Like Smart Phones, Games and Tablets, and in Online Search. Landmark Agreements Will Give Competitors Access to Standard-Essential Patents; Advertisers
} 
use tools to manage their advertising campaigns simultaneously on Google and on other competing advertising platforms, for example, Bing. ${ }^{56}$ Google agreed to settle and drop contractual restrictions on multi-homing. ${ }^{57}$ In a separate letter of commitment to the FTC Commission, Google has agreed to give online advertisers more flexibility to simultaneously manage ad campaigns on Google's AdWords platform and on rival ad platforms; and to refrain from misappropriating online content from so-called "vertical" websites that focus on specific categories such as shopping or travel for use in its own vertical offerings. ${ }^{58}$

In the EU investigations, the Commission is concerned that these restrictions create artificial switching costs which discourage advertisers using Google's AdWords from running parallel online search advertising campaigns on competing platforms, thereby reducing consumer choice. These restrictions do not yield any benefits for advertisers or consumers, but stifle the development of innovative campaign management tools. ${ }^{59}$ Customers ended up with limited choice while competitors of Google have been facing reduced incentives to innovate as Google's conduct limited their access to customers. ${ }^{60}$ Where network effects are particularly strong we can presuppose that the restriction on portability can be abusive. ${ }^{61}$

Google could try to defend itself on the basis of possible objective justifications. One of the main reasons for the growing importance of advertising in Google's business model lays in the merger between the search giant and

Will Get More Flexibility to Use Rival Search Engines, Press Release, January 3, 2013, in http://www. $\mathrm{ftc}$.gov/news-events/press-releases/2013/01/google-agrees-change-its-business-practices-resolve-ftc.

${ }^{56}$ Federal Trade Commission, Google Press Conference, Final Transcript, January 3, 2013, in http:// www.ftc.gov/sites/default/files/documents/videos/google-press-conference/130103google-pc.pdf.

${ }^{57}$ Federal Trade Commission, Google Press Conference, Opening Remarks of Federal Trade Commission Chairman Jon Leibowitz, Press Conference January 3, 2013. 4, in https:/www.ftc.gov/sites/default/ files/documents/public_statements/opening-remarks-federal-trade-commission-chairman-jon-leibowitz-prepared-delivery/130103googleleibowitzremarks.pdf.

${ }^{58}$ Federal Trade Commission, Google Agrees to Change Its Business Practices to Resolve FTC Competition Concerns in the Markets for Devices Like Smart Phones, Games and Tablets, and in Online Search. Landmark Agreements Will Give Competitors Access to Standard-Essential Patents; Advertisers Will Get More Flexibility to Use Rival Search Engines, Press Release, January 3, 2013, in http://www. $\mathrm{ftc}$.gov/news-events/press-releases/2013/01/google-agrees-change-its-business-practices-resolve-ftc.

${ }^{59}$ European Commission, Commission seeks feedback on commitments offered by Google to address competition concerns - questions and answers, MEMO/13/383, Brussels (April 25, 2013), http:// europa.eu/rapid/press-release_MEMO-13-383_en.htm.

${ }^{60} \mathrm{Ibid}$.

${ }^{61}$ Judgment of 17 September 2007, Microsoft Corp v. Commission, T-201/04, EU:T:2007:289, paragraph 562 . 
Double Click. ${ }^{62}$ The merger has allowed Google to apply an algorithm of a much higher quality and given it a competitive advantage, since Google and DoubleClick both operate on the same market that is online advertising Google provides online advertising space while DoubleClick is a seller of ad serving services. ${ }^{63}$

What is more, to provide advertising services, Google Search has developed a special AdWords platform. In AdWords, advertisers can select which words and phrases are relevant to their business and use them as their keywords. When Google's users conduct a search for these particular words, sponsored links are displayed alongside with search results. Each time a user clicks one of those sponsored links, the advertiser pays Google. ${ }^{64}$ Therefore, nowadays, Google's primary revenue derives from its provision of advertising services.

Few important particularities make Google's advertising system particularly successful. Firstly, this is because Google's ads are contextualised and personalised to match searchers' queries. Secondly, also the fact that Google operates worldwide draws many advertisers to Google. Thirdly, Google does not fix prices of "sponsored links" as they are organised according to the bidding system. Finally, advertisers are charged a price according to the so-called "cost per click", so if users are not directed to the advertisers' website, no additional cost need to be incurred, which is why online advertising is better tailored to the needs of advertisers than traditional one. ${ }^{65}$

Google could try to defend itself by claiming that information on how AdWords works and how to port advertising data from its advertising platform to others is a trade secret. Trade secret is valuable and confidential information that gives the enterprise a competitive advantage and can be therefore easily misappropriated. One cannot qualify as a trade secret an information that could be obtained from other sources on the market. ${ }^{66}$ Trade secret is not a form of IP right but it is closely analogous to

\footnotetext{
${ }^{62}$ See Google/ DoubleClick (Case COMP/M.4731), Regulation (EC) No 139/2004 Merger Procedure [2008], in http://ec.europa.eu/competition/mergers/cases/decisions/m4731_20080311_20682_en.pdf

${ }^{63}$ Sophie Van Loon, "The Power of Google: First Mover Advantage or Abuse of a Dominant Position?", in Empirical Approaches to Legal Aspects of Knowledge-Economy - Business Models, ed. Aurelio LopezTarruella, 22, Information Technology and Law Series (The Hague: T.M.C. Asser Press, 2012), 24.

${ }^{64}$ Aurelio Lopez-Taurrella, "Introduction: Google Pushing the Boundaries of Law", in Empirical Approaches to Legal Aspects of Knowledge-Economy - Business Models, ed. Aurelio Lopez-Tarruella, 22 Information Technology and Law Series (The Hague: T.M.C. Asser Press, 2012), 3.

${ }^{65} \mathrm{Ibid} ., 3-4$.

${ }^{66}$ Jonathan Faull and Ali Nikpay, op. cit., 155.
} 
patents, however it is chosen by the firms that prefer not to disclose the information. ${ }^{67}$ As the protection of trade secrets is not yet officially regulated in the whole EU, for now there are only national laws to be applied to such information. ${ }^{68}$ The directive on trade secrets is in preparation and aims to protect undisclosed know-how and business information (trade secrets) against their lawful acquisition, use and disclosure. ${ }^{69}$

A clear link between trade secrecy and innovation can be identified, namely

a firm that holds, as a secret, information that is valuable and that it makes reasonable efforts to protect can sue anyone who misappropriates the information. Firms tend to elect trade secrecy rather than patents when they do not wish to disclose information. But unlike the patent, copyright, and antitrust laws, the law of trade secrets has not erected innovation roadblocks. ${ }^{70}$

Google has already tried to justify the API's restriction because it ensures that third-party intermediaries take advantage of unique features available on AdWords. ${ }^{71}$ By restricting portability Google is therefore protecting itself from revealing how AdWords works and is trying to prevent free-riding. Sharing this information would deprive it from incentives to invest and innovate. This is because, although confidential information is uneconomical to duplicate, it is also easy to share and such sharing may be disastrous for Google's business. Moreover, we should be careful using a "convenience criterion" instead of factual and legal criteria for its application. Imposing a duty to share information "could discourage innovation, especially in the software industry" and there are also other alternative options for dealing with interoperability issues such as e.g. private antitrust actions. ${ }^{72}$

\footnotetext{
${ }^{67} \mathrm{Ibid} ., 1448$.

${ }^{68}$ See European Parliament and the Council, Proposal for a Directive on the Protection of Undisclosed Knowhow and Business Information (Trade Secrets) against Their Unlawful Acquisition, Use and Disclosure, COM/2013/0813, (2013), http://eur-lex.europa.eu/legal-content/EN/TXT/?uri=CELEX:52013PC0813. ${ }^{69}$ European Commission Trade Secrets (2016), http://ec.europa.eu/growth/industry/intellectual-property/trade-secrets/index_en.htm.

${ }^{70}$ Michael A. Carrier, op. cit., 21.

${ }^{71}$ John Thomas Rosch, "Concurring and Dissenting Statement of Commissioner J. Thomas Rosch Regarding Google's Search Practices - In the Matter of Google Inc., dissenting and concurring opinion", in The Matter of Google Inc., FTC File No. 111-0163 (2012), 6, https://www.ftc.gov/sites/default/ files/documents/public_statements/concurring-and-dissenting-statement-commissioner-j.thomasrosch-regarding-googles-search-practices/130103googlesearchstmt.pdf.

${ }^{72}$ Ibid.
} 


\subsubsection{Objective Justifications for Search Bias}

The alleged abuse of "search bias" has been considered pro-competitive and "competition on the merits" in the US, though the FTC was, as it had recently occurred, not unanimous on this issue. ${ }^{73}$ In the EU, the EC alleges that Google prominently displays links to its own specialised search services (in particular to its comparison shopping product, currently called "Google Shopping") within its web search results and does not seem to inform users of this favourable treatment. ${ }^{74}$

Google has been offering few sets of commitments to address these concerns, however, they were found unsatisfying. In its 2015 Statement of Objections the Commission raised its concerns that Google's conduct may artificially divert traffic from rival comparison shopping services and hinder their ability to compete, to the detriment of consumers, as well as stifle innovation. ${ }^{75}$

The European Commission has recently issued a supplementary statement of objections ${ }^{76}$ that deals with search bias in detail and provides additional evidence on the alleged abuse in question. The recent SO does not however bring new insight to the nature of the abuse itself and the Commission concerns remain unchanged since it has issued its main statement of objections issued in 2015. The EC outlines a broad range of additional evidence and data that supports the Commission's preliminary conclusions such as the way Google favours its own comparison shopping service over those of competitors, the impact of the website's prominence of display in Google's search results on its traffic, and the evolution of traffic to Google's comparison shopping service compared to its competitors. ${ }^{77}$ What is more, in recent response to Google's argument that while analysing comparison shopping the Commission should also take into account merchant platforms such

\footnotetext{
${ }^{73}$ See Brody Mullins et al., "Inside the U.S. Antitrust Probe of Google. Key FTC Staff Wanted to Sue Internet Giant after Finding 'Real Harm to Consumers and to Innovation"', The Wall Street Journal (2015), http://www.wsj.com/articles/inside-the-u-s-antitrust-probe-of-google-1426793274.

${ }^{74}$ European Commission, Commission seeks feedback on commitments offered by Google to address competition concerns - questions and answers, Memo, Brussels, April 25, 2013, MEMO/13/383, in http://europa.eu/rapid/press-release_MEMO-13-383_en.htm.

${ }^{75}$ European Commission, Antitrust: Commission Sends Statement of Objections to Google on Comparison Shopping Service, Fact Sheet, Brussels, (April 15, 2015), http://europa.eu/rapid/pressrelease_MEMO-15-4781_en.htm.

${ }^{76}$ European Commission, Antitrust: Commission Takes Further Steps in Investigations Alleging Google's Comparison Shopping and Advertising-Related Practices Breach EU Rules, Brussels (July 14, 2016), http://europa.eu/rapid/press-release_IP-16-2532_en.htm.

${ }^{77}$ Ibid.
} 
as Amazon and eBay, it has noted that these two areas should be placed in separate markets. However, even where they would be classified as belonging to the same relevant market, in the Commission's view, comparison shopping can be considered as such a significant part of the market, that Google's conduct resulted in weakening or even marginalising competition from its closest rivals. ${ }^{78}$ Nevertheless, according to Colomo, in recent years the industry has changed so much that Google is nowadays more like Amazon or eBay than a comparison website. ${ }^{79}$

It is, however, in Google's own interest to constantly improve its search and innovate. Innovation adds value to Google Search from the perspective of both consumers and advertisers ${ }^{80}$ Moreover, where Google, as a search engine, is designed to be subjective, that is to "point you to destination sites that have the information you are seeking, not to send you to other search engines", ${ }^{11}$ the fact that Google offers nowadays also vertical search engines can be a proof of it trying to create a better search experience. ${ }^{82}$ Google has been constantly improving its search services to match preferences of both searchers and advertisers. In recent years, Google's business model has changed significantly as regards offering search services, since it has moved into other areas of search such as weather predictions, flight tracking, currency conversion, etc. These specific areas of search offered by Google have moved from search results page up to above other organic search results. Google now keeps searchers on its own page instead of directing users to third-party websites. ${ }^{83}$ It is now in competition with other websites which also offer specific areas of search. ${ }^{84}$ Google offers a number of complementary services that improve search functionality and attract searchers to its search engine. These include e.g. Google News, Google Images, Google Patents, Google Scholar, etc. On the one hand, offering such complementary services is a "co-investment" which means that "the more you use it,

\footnotetext{
${ }^{78}$ Ibid.

${ }^{79}$ Pablo Ibáñez Colomo, "What to Make of the Fresh Charges against Google", Chillin' Competition (2016), https://chillingcompetition.com/2016/07/15/what-to-make-of-the-fresh-charges-againstgoogle/.

${ }^{80}$ Robert H. Bork and J. Gregory Sidak, "What Does the Chicago School Teach about Internet Search and the Antitrust Treatment of Google?", Journal of Competition Law and Economics 8, 4 (2012): 666.

${ }^{81}$ Danny Sullivan, The Incredible Stupidity of Investigating Google for Acting like a Search Engine (2010), http://searchengineland.com/the-incredible-stupidity-of-investigating-google-for-actinglike-a-search-engine-57268.

${ }^{82} \mathrm{Ibid}$.

${ }^{83}$ Eric Goldman, “Revisiting Search Engine Bias", William Mitchell Law Review 38, 1 (2011): 103.

${ }^{84}$ Ibid.: 104.
} 
the more it can tailor its offerings to you" ${ }^{85}$ On the other hand, these services are offered to keep users within services offered by Google. Moreover, it is also in Google's own interest to constantly improve its search and innovate. Innovation adds value to Google Search from the perspective of both consumers and advertisers. ${ }^{86}$ Where Google as a search engine is designed to be subjective, that is to "point you to destination sites that have the information you are seeking, not to send you to other search engines" ${ }^{87}$ the fact that Google offers nowadays also vertical search engines can be a proof of it trying to create a better search experience. ${ }^{88}$

There is therefore little doubt that Universal Results and One Boxes improve quality of results for users compared with the display of a list of blue links. Results are displayed in a more user-friendly and organised way. Consequently, although a number of vertical search engines complain that their prominence and visibility in internet searches has worsened, this situation may be the result of competition on the merits and not an anticompetitive practice that negatively affects innovation. ${ }^{89}$ What is more, perhaps Google has no incentive to exclude better services. Where specialised search-segment does not seem to be competitive enough, it may be better for Google to become involved in such services itself, especially as the market for specialised search services is expanding. Integration of general search with vertical one can also be a strategy aiming at avoidance of a double-marginalisation problem. ${ }^{90}$ However, search bias may deter better services for searchers/buyers, as well as monopolise matchmaking of searchers/buyers and advertisers/sellers. ${ }^{91}$

What is more, Google itself is trying to justify its involvement in search bias using the so-called "convenience" argument. It is assuming that consumers are better off when they e.g. find a desired address in a few seconds; as such information is ready and available in Google's Maps. Google may be right to assume that consumers do prefer to find the desired information faster. This is because many of the consumers in their status quo-state

\footnotetext{
${ }^{85}$ Pasquale, op. cit., 9.

${ }^{86} \mathrm{Ibid}$.

${ }^{87}$ Sullivan, op. cit.

${ }^{88} \mathrm{Ibid}$.

${ }^{89}$ Renato Nazzini, "Google and the (Ever-stretching) Boundaries of Article 102 TFUE", Journal of European Competition Law \& Practice 6, 5 (2015): 308.

${ }^{90}$ Lars Wiethaus, "Google’s Favouring of Own Services: Comments from an Economic Perspective", Journal of European Competition Law and Practice 6, 7 (2015): 509.

${ }^{91}$ Ibid.: 510.
} 
most probably do not even wonder or complain why it is so convenient to conduct such a search. In this matter, Google is using the fact that consumers are often biased in their decisions and that their decisions are rather intuitive than conscious. ${ }^{92}$ The fact that Google is the largest search engine and the most popular one too, may also have much to do with the fact that it provides search results much quicker and they are also more accurate. ${ }^{93}$ Because Google constantly improves the design of its algorithm, impairing such improvements could be more harmful than useful. Algorithm requires a constant adaptation to users' search needs, if Google wished to profit from online search. Innovation is a better tool for addressing algorithms than lengthy regulatory process. ${ }^{94}$ Changes to Google's algorithm that had the effect of demoting certain competing websites had some plausible connection with improving Google's search results, especially when competitors often tried to game Google's algorithm in ways that benefited those firms, but not consumers looking for the best search results. According to Google, its rivals engaged in many of the same product design choices that Google did, suggesting that this practice benefits consumers. ${ }^{95}$

\subsection{Effect of Practice on Consumers}

Another sphere where innovation comes into play when assessing possible anti-competitiveness of an abuse in question is when the effect of the practice on consumers is being analysed. When analysing exclusionary abuses the Commission recommends focusing on an abuse that leads to a foreclosure which hinders competition and thereby harms consumers. ${ }^{96}$ Even though the courts do not require consumer harm as a proof of foreclosure, the Commission recommends considering it in the analysis.

According to the EC, to foreclose, the dominant undertaking should be able to influence to its own advantage and to the detriment of consumers

\footnotetext{
${ }^{92}$ See Daniel Kahneman, Thinking Fast and Slow (London: Penguin Books, 2012).

${ }^{93}$ Daniel Zimmer, "Digital Markets. New Rules for Competition Law", Journal of Competition Law and Practice 6, 9 (2015): 627.

${ }^{94}$ Howard Shelanski, op. cit.: 1695-1696.

${ }^{95}$ Federal Trade Commission, Google Press Conference, Opening Remarks of Federal Trade Commission Chairman Jon Leibowitz, Press Conference January 3, 2013, 5, accessed 22 March 2016. https://www. $\mathrm{ftc} . g o v /$ sites/default/files/documents/public_statements/opening-remarks-federal-trade-commission-chairman-jon-leibowitz-prepared-delivery/130103googleleibowitzremarks.pdf.

${ }^{96}$ European Commission, Guidance on the Commission's Enforcement Priorities in Applying Article 82 of the EC Treaty to Abusive Exclusionary Conduct by Dominant Undertakings, OJ C45/02, 2009, paragraph 19.
} 
at least some parameters of competition such as e.g. prices, output, innovation, the variety or quality of goods or services. ${ }^{97}$ (Therefore, while assessing the impact of the abuse on consumer welfare, we look whether it leads to any inefficiencies. Antitrust is based on a premise that competitive markets are ones where not only "allocative efficiencies" and "productive efficiencies" occur, but also innovative and dynamic efficiencies. ${ }^{98}$ In digital markets, we should increasingly focus on dynamic efficiencies which denote harm to innovation.

Under the EU competition law, there is yet no possibility of claiming that direct harm to innovation has occurred. Instead, one should first prove that the practice indirectly leads to anticompetitive foreclosure that has also affected innovation. ${ }^{99}$ This is because exclusionary practices are considered an alternative to innovation, and therefore may cause competitive problems in industries which are primarily concerned with innovation. Exclusion would be considered as the supreme evil if innovation would be taken into account. ${ }^{100}$ It is therefore more evitable to introduce the claims based on consumer harm indirectly, for example by showing that the behaviour in question lessens consumer choice, etc., or impedes disruptive innovation by aiming at the exclusion of rivals.

In fact, "consumer choice" may well be a much better criterion for identifying a restraint of competition in innovation-related cases than the more general "consumer harm". The consumer choice criterion leaves the decision of what should be preferred in the market to consumers themselves. ${ }^{101}$ As competition agencies are unable to correctly predict the future preferences of consumers, they may be better off letting consumers decide for themselves. ${ }^{102}$ Competition policy should then aim at making new products

\footnotetext{
${ }^{97}$ Ibid., paragraph 11.

${ }^{98}$ Steven Anderman and Hedvig Schimdt, EU Competition Law and Intellectual Property Rights. The Regulation of Innovation (Oxford: Oxford University Press, 2011), 14.

${ }^{99}$ Pablo Ibáñez Colomo, "Restrictions on Innovation EU Competition Law", European Law Review (forthcoming) 41 (2016), 3, https://www.lse.ac.uk/collections/law/wps/WPS2015-22_Colomo.pdf.

${ }^{100} \mathrm{Tim} \mathrm{Wu}$, “Taking Innovation Seriously: Antitrust Enforcement if Innovation Mattered Most", Antitrust Law Journal 78, 2 (2012): 316.

${ }^{101}$ Joseph Drexl, "Real Knowledge is to Know the Extent of One's Own Ignorance: the Consumer Harm Approach in Innovation-Related Competition Cases", Max Plank Institute for Intellectual Property, Competition and Tax Law Research Paper Series 9, 15 (2009): 32-33, http://papers.ssrn.com/ sol3/papers.cfm?abstract_id=1517757.

${ }^{102}$ Ibid., 3-4.
} 
available so that consumers could affect the demand for particular products and benefit from it. ${ }^{103}$

\subsubsection{Consumer Harm in Restrictions on Portability of Online Advertising Data}

To port online advertising data used in Google's AdWords campaigns to other advertising platforms, advertisers would need to get an access to Application Program Interfaces (hereinafter APIs). API can be defined as "a user interface for machines to access machines", 104 and allow communication between computer programs and hardware. In order for others to use APIs, it has to be either published or licensed, otherwise the use of such APIs would be considered as a breach of copyright. ${ }^{105}$ Examples of APIs include interfaces between an operating system and the programs that run on it (to allow the programs access to the computer's screen, keyboard and file system, for example); the interface allowing a program to accept plug-ins providing additional functionality, such as Photoshop or Mozilla Firefox; the interface allowing software programs to interact with Google Maps, Gmail, Facebook and Twitter. ${ }^{106}$ In Google's advertising platform, APIs would allow advertisers to develop their own software programs to automatically manage and optimize their advertising campaigns. ${ }^{107}$

Do restrictions on portability of advertising data reduce consumer choice or prevent the occurrence of new or better products? The Commission is concerned that these restrictions on porting the data create artificial switching costs which discourage advertisers using Google's AdWords from running parallel online search advertising campaigns on competing platforms, thereby reducing consumer choice. These restrictions do not yield any benefits for advertisers or consumers, but stifle the development of innovative campaign management tools. Customers end up with limited choice while Google's competitors face reduced incentives to innovate as Google's

\footnotetext{
${ }^{103}$ Sidak and Teece, op. cit., 600.

${ }^{104}$ Andrew Katz, "Google, APIs and the Law", in Empirical Approaches to Legal Aspects of KnowledgeEconomy - Business Models, ed. Aurelio Lopez-Tarruella, 22, Information Technology and Law Series, (The Hague: T.M.C. Asser Press, 2012), 287.

${ }^{105}$ Ibid., 289-290.

${ }^{106}$ Ibid., 288.

${ }^{107}$ Federal Trade Commission, Google Agrees to Change Its Business Practices to Resolve FTC Competition Concerns in the Markets for Devices Like Smart Phones, Games and Tablets, and in Online Search. Landmark Agreements Will Give Competitors Access to Standard-Essential Patents; Advertisers Will Get More Flexibility to Use Rival Search Engines, Press Release, January 3, 2013, http://www.ftc. gov/news-events/press-releases/2013/01/google-agrees-change-its-business-practices-resolve-ftc.
} 
conduct limited their access to customers. ${ }^{108}$ According to the European Commission, where a publisher (the website owner) is only allowed to place advertisement that has been provided by Google and cannot display at all, or only to a limited extent, advertisements from other companies, web users are limited in their choice. As Google is also a major search advertising intermediator, this reduces the availability of services to consumers and accordingly inhibits innovation. ${ }^{109}$

Are restrictions on portability of advertising data indeed affecting innovation? To answer this question, one should analyse whether it would be too expensive on impractical for Google's competitors to create similar campaigns on competing advertising platforms and consequently, increase consumer choice. Similar campaigns available on different platforms would probably increase the consumer choice as to the number of services, but not necessarily the quality. What is more, are there other methods of porting the data? ${ }^{110}$

Creating a second system like AdWords would not lead to large duplication costs. ${ }^{111}$ Moreover, in the US investigations, the FTC's Commissioner Rosh noted that the restrictions in question prevented licensees from using software developed or used by a third party (but not the advertiser itself) to comingle data and simultaneously manage an ad campaign involving both Google and the rivals. The restriction did not prevent users from exporting AdWords data onto a rivals' platform, which would need to be done with their own software. ${ }^{112}$ These alternative options of porting data are definitely less advantageous, however, they are available. One should point out

\footnotetext{
${ }^{108}$ European Commission, Commission seeks feedback on commitments offered by Google to address competition concerns - questions and answers, Memo, Brussels, April 25, 2013, MEMO/13/383, http:// europa.eu/rapid/press-release_MEMO-13-383_en.htm.

${ }^{109}$ Ibid.

${ }^{110}$ See Judgment of 26 November 1998, Oscar Bronner GmbH Co KG v Mediaprint Zeitungs- und Zeitschriftenverlag $\mathrm{GmbH}$ \& Co. KG, Mediaprint Zeitungsvertriebsgesellschaft $m b H$ \& Co. KG and Mediaprint Anzeigengesellschaft mbH \& Co. KG, C-7/97, EU:C:1998:569, paragraph 43.

${ }^{111} \mathrm{Ibid}$., paragraph 46.

${ }^{112}$ John Thomas Rosch, "Concurring and Dissenting Statement of Commissioner J. Thomas Rosch Regarding Google's Search Practices - In the Matter of Google Inc., dissenting and concurring opinion", in The Matter of Google Inc., FTC File No. 111-0163 (2012): 4, https://www.ftc.gov/sites/default/ files/documents/public_statements/concurring-and-dissenting-statement-commissioner-j.thomasrosch-regarding-googles-search-practices/130103googlesearchstmt.pdf.
} 
that advertisers usually do use programs of third parties to port the data and rarely can do that by themselves. ${ }^{113}$

Nevertheless, we cannot deny the existence of alternative ways available for rivals to create own advertising campaigns. According to FTC, faced with restrictions on portability advertisers could develop their own software programs that would allow them to move the data from one campaign to another, however it is quite costly for them to develop own programs. Moreover, as advertisers are more acquainted with using third parties' software to port the data instead, in order for the software programmers to create such a software, they would need to be provided with interoperability information in the form of APIs. ${ }^{114}$

As we have pointed out before, the EU competition law cannot use the theory of harm based solely on harm to innovation, here, lessened consumer choice, without the prove of foreclosure. It is enough that, in the absence of actual foreclosure, the risk of it is possible in the long-run. Therefore, although at the moment advertising platforms are still able to compete with Google and provide advertisers with advertising campaigns, a potential threat exists that due to Google's restrictions on portability, combined with exclusive obligations and Google's possession of users' data, other advertising platforms will not be able to compete on equal terms.

Moreover, potential foreclosure may also derive from the fact that Google's advertising platform is considered by advertisers as a de facto standard and unavoidable trading partner. Standards can have several positive effects, such as obvious welfare effects, ensuring compatibility and interoperability between products from different vendors. In the result of allowing compatibility and interoperability products offered by different firms can be combined and used together and this increases consumer choice and convenience and reduces costs. ${ }^{115}$ Conversely, when such interoperability is denied, these positive effects would not occur, to the detriment of consumers. Therefore, large platforms such as Google often choose either to provide

\footnotetext{
${ }^{113}$ Judgment of 29 April 2004, IMS Health GmbH \& Co OHG v NDC Health GmbH \& Co KG, C-418/01, EU:C:2004:257, paragraph 44.

${ }^{114}$ Federal Trade Commission, Google Agrees to Change Its Business Practices to Resolve FTC Competition Concerns in the Markets for Devices Like Smart Phones, Games and Tablets, and in Online Search. Landmark Agreements Will Give Competitors Access to Standard-Essential Patents; Advertisers Will Get More Flexibility to Use Rival Search Engines, Press Release (January 3, 2013), http://www. $\mathrm{ftc.gov/news-events/press-releases/2013/01/google-agrees-change-its-business-practices-resolve-} \mathrm{ftc}$. ${ }^{115}$ Miguel De La Mano, “Competition policy, the "O-ring” of the Patent System?", Annual CRA Conference (Brussels, 2011).
} 
open access to the platform or to make interoperability difficult. This may lead to occurrence of such negative effects of standards.

To compete with Google on equal foot, its rivals would have to offer a completely new way of advertising on the Internet that would be so much better and efficient that it could overcome path-dependence and allow consumers to switch to that new service without significant switching costs. Alternatively, Google's rivals would be able to compete if they could gather as significant volumes of users' data as Google has. This is highly unlikely because Google as a fist-mover enjoys strong network effects that tipped the market towards Google's standard. Finally, it also seems that Google has managed to develop a very successful business model that is difficult to compete with, therefore, to address this issue EC could impose on Google an order to allow interoperability from Google so that competitors can in fact compete on improved products.

As we have pointed out earlier, consumer harm could be assessed by analysing whether consumer choice is being limited. Nevertheless, this may be a daunting task where Google operates as a two-sided market, one that brings together two interdependent groups of consumers, namely advertisers and searchers. Therefore, is it enough that restrictions on portability harm only one group of Google's consumers or do we need to prove harm to both sides? Advertisers are clearly limited in their choice as they can only place advertisements with Google, or mostly with Google. They will most probably not switch to competing platforms as these do not have as high volumes of personal data as Google and are therefore unable to target searchers with advertisements that would be as accurately matching their previous searches and preferences as the ones offered by Google. Moreover, due to limited choice, advertisers also end up paying higher prices than they would if they could move their AdWords-based ads elsewhere. What is more, searchers do not seem to care about advertisements that much, as they would even prefer search results that do not link to ads at all. They are however tolerating the ads as this is the cost of search being offered for free.

It seems that the practice in question does in fact limit the choice of advertisers and may potentially exclude them from the market. The practice prevents "multi-homing", which denotes that consumers use more than one website or application for specific tasks. ${ }^{116}$ When users multi-home, they

\footnotetext{
${ }^{116}$ Oxera, Benefits of Online Platforms, Report Prepared for Google (2015), http://www.oxera.com/ getmedia/84df70f3-8fe0-4ad1-b4ba-d235ee50cb30/The-benefits-of-online-platforms-mainfindings-\%28October-2015\%29.pdf.aspx?ext=.pdf.
} 
could be targeted with the same ads on different online platforms. Multihoming is a popular practice on the Internet and may be highly beneficial for its users. It also lessens the chance that the market will tip towards one dominant standard and ensures more competition on the market. ${ }^{117}$ Since multi-homing can be encouraged by an increased interoperability between different platforms it invites competition from smaller networks, therefore preventing tipping towards one dominant standard. However, it can also diminish the significance arising from cross-platform network effects. ${ }^{118}$ Therefore, if special responsibility of a dominant advertising platform could be entrenched so that publishers could use not only multiple platforms, but also one single interface for managing multiple advertising campaigns, allowing portability of advertising data between Google and its competitors could lead to an increased competition in the search advertising market and therefore increased consumer choice.

As at this moment it is highly unlikely that any other search engine can gain as many users as Google, this may change once portability is allowed. However, this does not seem to hold where we take into account the fact that users multi-home even without interoperability information and the range of substitutes for AdWords is wider than expected. For example, advertisers can now put their advertisements on vertical search engines, such as Instagram, Facebook, etc. Moreover, although from consumer welfare's point of view it would be better that the system of open standards and full interoperability is implemented, it would only be feasible if the dominant firm would not chill innovation as to result in a net welfare loss. ${ }^{119}$ Imposing a duty to share information on how advertising data is ported could discourage innovation. ${ }^{120}$

As we have pointed out in the part on objective justifications available to Google as to restrictions on portability, Google could try to defend itself on the basis that it has heavily invested in AdWords and information on how to port the advertising data could be considered as a trade secret.

\footnotetext{
${ }^{117} \mathrm{Ibid}$.

${ }_{118}$ Andres V. Lerner, "The Role of 'Big Data' in Online Platform Competition” (2014), 60, accessed 23 March 2016. http://awards.concurrences.com/IMG/pdf/big.pdf.

${ }^{119}$ Marina Lao, "Networks, Access, and 'Essential Facilities': from Terminal Railroad to Microsoft", SMU Law Review 62, 2 (2009): 561.

${ }^{120} \mathrm{Ibid}$.
} 


\subsubsection{Consumer Harm in Search Bias}

Recent developments prove that search bias is a more complex problem and can be seen as both an anticompetitive practice and competition on the merits. According to the European Commission, Google prominently displays links to its own specialised search services (in particular to its comparison shopping product, currently called "Google Shopping" within its web search results and does not seem to inform users of this favourable treatment. ${ }^{121}$ The Commission therefore explicitly stated that this behaviour

(...) may therefore artificially divert traffic from rival comparison shopping services and hinder their ability to compete on the market. The Commission is concerned that users do not necessarily see the most relevant results in response to queries - this is to the detriment of consumers, and stifles innovation. ${ }^{122}$

The EC has pointed out that since Google is an important source of traffic for competing specialised search services, search bias may also reduce competitors' incentives to innovate in specialised search. ${ }^{123}$ Search bias may lead to the harm to innovation because it reduces "incentives of existing and potential vertical search engines to invest in innovative and disruptive technologies of specialised search"124 and it also causes "harm by slowing evolution of search technology in general". ${ }^{125}$

Moreover, according to the EC, Google's systematic favouring of its subsequent comparison shopping services "Google Product Search" and "Google Shopping" led to higher rates of growth, to the detriment of rival comparison shopping services. ${ }^{126}$ This is especially relevant as in the market for comparison shopping, where Google is facing competition from several

\footnotetext{
${ }^{121}$ European Commission, Commission seeks feedback on commitments offered by Google to address competition concerns - questions and answers, MEMO/13/383 Brussels (April 25, 2013), http://europa. eu/rapid/press-release_MEMO-13-383_en.htm.

${ }^{122}$ European Commission, Antitrust: Commission sends Statement of Objections to Google on comparison shopping service; opens separate formal investigation on Android, Press Release, IP/15/4780, Brussels (April 15, 2015), http://europa.eu/rapid/press-release_IP-15-4780_en.htm.

${ }^{123}$ Ibid.

${ }^{124}$ Luca et al., "Does Google Content Degrade Google Search? Experimental Evidence", Harvard Business School NOM Unit Working Paper 16, 35 (2015): 20, http://ssrn.com/abstract=2667143.

${ }^{125}$ Ibid.: 21.

${ }^{126}$ European Commission (2015), Antitrust: Commission sends Statement of Objections to Google on comparison shopping service; opens separate formal investigation on Android, Press Release, Brussels, 15 April 2015, IP/15/4780, in http://europa.eu/rapid/press-release_IP-15-4780_en.htm (16.04.2015).
} 
alternative providers, such a behaviour could possibly be highly exclusionary. What is more, Google does not apply to its own comparison shopping service the system of penalties, which it uses in relation to other comparison shopping services based on defined parameters, and which can lead to the lowering of the rank in which they appear in Google's general search results pages. Froogle, Google's first comparison shopping service, did not benefit from any favourable treatment, and performed poorly. ${ }^{127}$

According to the EC, since users do not necessarily see the most relevant comparison shopping results in response to their queries, Google rivals' incentives to innovate are lowered as they know that however good their product, they will not benefit from the same prominence as Google's product. ${ }^{128}$ The Commission is of the opinion that many of the vertical services that are potentially foreclosed by Google might be innovative and Google's practices could be therefore limiting opportunities of European consumers to benefit from such innovative services. At the same time, it is for users to decide whether they wish to visit these sites based on their merits. ${ }^{129}$

However, searchers look for information on the Internet using alternative sources which are not characterised as general search engines. ${ }^{130}$ Consumers do not seem to be harmed directly and they do seem to be able to choose between using Google and additional vertical search engines. This is especially relevant in regard to vertical search engines that offer information on travelling, music, books, ones that are specialising in sharing pictures, music, etc. Therefore, it does not seem that the use of Google is essential in a strict sense of essentiality, as alternatives do exist. ${ }^{131}$

In Google's view, the Commission does not seem to recognise the benefits to consumers and advertisers that Google's business creates. Moreover, it claims that the Commission did not back the claim up or provide a clear

\footnotetext{
${ }^{127} \mathrm{Ibid}$.

${ }^{128}$ European Commission (2015), A Digital Single Market Strategy for Europe, Communication to the European Parliament, the Council, the European Economic and Social Committee and the Committee of the Regions, COM (2015) 192 final.

${ }^{129}$ European Commission (2013), Commission seeks feedback on commitments offered by Google to address competition concerns - questions and answers, Memo, Brussels, 25 April 2013, MEMO/13/383, in http://europa.eu/rapid/press-release_MEMO-13-383_en.htm.

${ }^{130}$ Marina Lao, "Neutral Search as a Basis for Antitrust Action?", Harvard Journal of Law and Technology 26, 2 (2013): 7, http://jolt.law.harvard.edu/antitrust/articles/Lao.pdf.

${ }^{131}$ Ibid., 8.
} 
legal theory to connect its claims with its proposed remedy. ${ }^{132}$ Nor does it recognise the presence of other major shopping services like Amazon or eBay in the market or the fact that Google has succeeded to develop new ways to organize and rank product information and to present it to users in useful formats in search and ads. ${ }^{133}$

Competitors may be also foreclosed due to strong network effects, namely trial-and-learning effects. Due to these network effects, search results provided by Google may be still, even despite being biased, of higher quality than the ones offered by its competitors, such as Bing or Yahoo!. This is because competitors lack user data that make search more accurate since Google can offer search results that are adjusted to users' preferences. Each search feeds into Google's algorithm by providing specific information on what is being searched, by whom and how often. This information is given by searchers for free in exchange for free search. The so-called "big data" give Google a significant advantage over rivals that is based on economies of scale and scope. For a new entrant it may be difficult to predict search terms as he will lack the scale of trial-and-errors experimentation. The incumbent has then a competitive advantage over entrants. ${ }^{134}$

\section{Conclusions}

It is not easy for small companies to take over the market with disruptive innovation, however, it is also not entirely impossible, especially in digital markets which often do not require expensive pre-investments and long prior phases of Research and Development. Competition policy has therefore a larger role for disruptive innovation, as due to its radical nature, it has a larger impact on consumer welfare and existential threat to rivals. Therefore, especially as disruptive innovations may be undergone without incurring significant costs, digital monopolists will aim at excluding their rivals from the market and preventing the disruptive innovation from succeeding. This may be done by leveraging their monopolistic position into other adjacent markets, where disruptive rivals are present.

\footnotetext{
${ }^{132}$ Google, Improving Quality Isn't Anti-Competitive, Google Europe Blog (2015), http://googlepolicyeurope.blogspot.fi/2015/08/improving-quality-isnt-anti-competitive.html. (23.03.2016). See also Google, "Improving Quality Isn't Anticompetitive Part II", Google in Europe Blog (2016), https://blog. google/topics/google-europe/improving-quality-isnt-anti-competitive-part-ii/.

${ }^{133} \mathrm{Ibid}$.

${ }^{134}$ Stucke, op. cit., 555.
} 
Nevertheless, a digital monopolist is still more likely to invest in sustaining innovation due to revenues he is able to collect from his main area of operation as well as from the possible revenues it earns by leveraging its dominant position to adjacent markets. However, even the digital monopoly is only temporary and it is not immune to disruptive innovations that can come from other market players or from the outside. Therefore, it is disruptive innovation that the EC should be promoting and it should monitor whether incumbents do not aim at excluding its rivals from the market to prevent this particular kind of technological innovation. The discussion between Schumpeter v. Arrow is still up-to-date, however the latter should prevail in digital markets as the idea that a monopolist that is more eager to innovate has to be confronted with technological, fast-moving markets which are also based on complements.

For example, Google has more revenue to invest in innovations as due to the possession of large amounts of big data, it can earn more profits from advertising that can be used later on to sponsor its leveraging attempts to other, adjacent markets. Google may aim at excluding its rivals from the market to prevent disruptive innovation, however, it is doubtful whether it can in fact succeed in doing so.

In this article, the following questions were asked: (a) whether Google could defend itself by the use of objective justifications based on innovation or (b) is the European Commission able to prove that, besides (or absent the requirement of) anticompetitive exclusion, the practice in question also causes dynamic inefficiency in the form of limited consumer choice or deterring the development of new and improved products? It seems that introduction of innovation considerations works better as regards objective justifications. Digital monopolies do not seem to be under the pressure of any particular higher threshold of special responsibility and should therefore be able to defend themselves by the use of objective justifications. In particular, Google could claim that information on how to port advertising data is a trade secret that it does not wish to reveal to prevent free-riding on its investment. Moreover, as to search bias, Google could claim the popularity of its search engine derives from increased investment efforts and an attempt to promote its vertical services is aimed at improving the user experience.

When assessing the impact of an allegedly anticompetitive abuse, one, in the current state of the EU law, cannot use direct harm to innovation as a working proxy, as this harm may be only transitory or not so clear-cut. 
Instead, it can be shown that the practice in question, besides excluding competitors, also indirectly leads to dynamic inefficiencies such as lessened incentives to invest and innovate or lessened consumer choice. It is ambiguous whether EU competition law should be updated to invite direct application of harm to innovation as a possible theory of harm. Perhaps such an approach would better suit digital markets.

Using innovation consideration as a proof of consumer harm would denote focusing on increased consumer choice and new and better products. Therefore, where the behaviour of the digital monopolist leads to exclusion and the mentioned form of consumer harm, it could be considered as anticompetitive. Restrictions on portability of online advertising platforms are not total restrictions and advertisers could design ways to port data by themselves, without the help of third parties, however, this is highly unlikely. As at this moment it is highly unlikely that any other search engine can gain as many users as Google, this may change once portability is allowed. However, this does not seem to hold where we take into account the fact that users multi-home even without interoperability information and the range of substitutes for AdWords is wider than expected. For example, advertisers can now put their advertisements on vertical search engines, such as Instagram, Facebook, etc. Therefore, consumer choice is not totally limited. Similarly, as regards search bias, searchers shop on the Internet by increasingly using alternative sources such as Amazon or eBay.

Innovation in digital platforms is not an episodic activity, but a component of an industry, and R\&D is the central input of production. Therefore, e.g. search engines need to revise and refine their algorithms to match consumer queries to search results. ${ }^{135}$ Consequently, no digital product or service stays the same as its features and functionality change on the daily basis. What is more, innovation in digital markets is conducted not only by companies offering the products or services, but also by customers themselves as they figure out new ways of using digital platforms and applications on their own advantage. ${ }^{136}$

\footnotetext{
${ }^{135}$ Shelanski, op. cit., 1685.
}

${ }^{136}$ Ibid. 


\section{Bibliography}

Anderman, Steven and Hedvig Schmidt. EU Competition Law and Intellectual Property Rights. The Regulation of Innovation. Oxford: Oxford University Press, 2011.

Arrow, Kenneth J. "Economic Welfare and the Allocation of Resources for Invention", in The Rate and Direction of Inventive Activity: Economic and Social Factors, edited by Universities-National Bureau Committee for Economic Research, Committee on Economic Growth of the Social Science Research Council, 609-626. Princeton: Princeton University Press, 1962.

Bardey, David, Helmuth Cremer and Jean-Marie Lozachmeur. "Competition in Two-sided Markets with Common Network Externalities", Review of Industrial Organisation 44 (2014): 327-345.

Bork, Robert H. and J. Gregory Sidak. "What Does the Chicago School Teach about Internet Search and the Antitrust Treatment of Google?", Journal of Competition Law and Economics 8, 4 (2012): 663-700.

Carlton, Dennis and Jeffrey Perloff. Modern Industrial Organization. New York: Harper Collins, 2003.

Carrier, Michael A. Innovation for the 21st Century, Harnessing the Power of Intellectual Property and Antitrust Law. New York: Oxford University Press, 2009.

Christensen, Clayton M. and Michael E. Raynor. The Innovator's Solution: Creating and Sustaining Successful Growth. Boston, Massachusetts: Harvard Business Review Press, 2013.

Colomo, Pablo Ibáñez. "Restrictions on Innovation EU Competition Law", European Law Review (forthcoming), 41 (2016), https:/www.lse.ac.uk/collections/law/wps/ WPS2015-22_Colomo.pdf.

Colomo, Pablo Ibáñez. "What to Make of the Fresh Charges against Google", Chillin' Competition, accessed 15 July 2016. https://chillingcompetition.com/2016/07/15/ what-to-make-of-the-fresh-charges-against-google/.

De la Mano, Miguel. "Competition policy, the "O-ring” of the Patent System?", Annual CRA Conference. Brussels, 2011.

De Streel, Alexandre and Pierre Larouche. "Disruptive Innovation and Competition Policy Enforcement", Organisation for Economic Co-Operation and Development, Global Forum for Competition, Session III, 3 DAF/COMP/GF (October 20, 2015), https://papers.ssrn.com/sol3/papers.cfm?abstract_id=2678890.

Drexl, Joseph. "Real Knowledge is to Know the Extent of One's Own Ignorance: the Consumer Harm Approach in Innovation-Related Competition Cases", Max Plank Institute for Intellectual Property, Competition and Tax Law Research Paper Series 9, 15 (2009), http://papers.ssrn.com/sol3/papers.cfm?abstract_id=1517757.

Evans, David S. “The Antitrust Economics of Multi-Sided Platform Markets", Yale Journal on Regulation 20, 2 (2003): 325-381. 
Faull, Jonathan and Ali Nikpay eds., Faull and Nikpay: The EU Law of Competition, $3^{\text {rd }}$ ed. Oxford: Oxford University Press, 2014.

Goldman, Eric. "Revisiting Search Engine Bias", William Mitchell Law Review 38, 1 (2011): 96-110.

Google. "Improving Quality Isn't Anti-Competitive Part II", in Google Europe Blog (3 November 2016, in https://blog.google/topics/google-europe/improving-quality-isnt-anticompetitive-part-ii/.

Google Europe Blog. http://googlepolicyeurope.blogspot.fi/.

Hagiu, Andrei and Julian Wright. "Multi-Sided Platforms", International Journal of Industrial Organization 43 (2015): 162-174.

Hovenkamp, Hebert J. “Competition for Innovation”, University of Iowa, Legal Studies Research Paper, 13, 26 (2013), https://papers.ssrn.com/sol3/papers.cfm?abstract-id=2008953.

Italianer, Alexander. “Competition Policy in the Digital Age”, $47^{\text {th }}$ Innsbruck Symposium - Real sector economy and the Internet - digital interconnection as an issue for competition policy, accessed 7 March 2014, http://ec.europa.eu/competition/speeches/text/sp2014_01_en.pdf.

Kahneman, Daniel. Thinking Fast and Slow. London: Penguin Books, 2012.

Karlgaard, Richard. The Soft Edge: Where Great Companies Find Lasting Success. San Francisco: Jossey-Bass, 2014.

Katz, Andrew. "Google, APIs and the Law", in Empirical Approaches to Legal Aspects of Knowledge-Economy - Business Models, edited by Aurelio Lopez-Tarruella, 22 Information Technology and Law Series, 287-301, The Hague: T.M.C. Asser Press, 2012. Lopez-Tarruella, Aurelio. "Introduction: Google Pushing the Boundaries of Law", in Empirical Approaches to Legal Aspects of Knowledge-Economy - Business Models, edited by Aurelio Lopez-Tarruella, 22 Information Technology and Law Series, 1-8, The Hague: T. M. C. Asser Press, 2012.

Lao, Marina. "Networks, Access, and 'Essential Facilities': from Terminal Railroad to Microsoft", SMU Law Review 62, 2 (2009): 557-596.

Lao, Marina. "Neutral Search as a Basis for Antitrust Action?", Harvard Journal of Law and Technology 26, 2 (2013), http://jolt.law.harvard.edu/antitrust/articles/Lao.pdf.

Lerner, Andres V. "The Role of 'Big Data' in Online Platform Competition" (2014), accessed 23 March 2016. http://awards.concurrences.com/IMG/pdf/big.pdf.

Luca, Michael, Sebastian Couvidat, Daniel Frank, William Seltzer and Timothy Wu. "Does Google Content Degrade Google Search? Experimental Evidence", Harvard Business School NOM Unit Working Paper 16, 35 (2015), http://ssrn.com/ abstract $=2667143$.

Lundqvist, Björn. Standardization under EU Competition Rules and US Antitrust Laws. The Rise and Limits of Self-Regulation. Cheltenham, UK/Northampton, Massachusetts: Edward Elgar, 2014. 
Monopolkommission. Competition Policy: The challenge of digital markets. Special Report by the Monopolies Commission Pursuant to Section 44(1) (4) of the Act against Restraints on Competition, (June 1, 2015), http://www.monopolkommission.de/ images/PDF/SG/SG68/S68_summary.pdf.

Mullins, Brody, Brent Kendall and Rolfe Winkler. "Inside the U.S. Antitrust Probe of Google. Key FTC Staff Wanted to Sue Internet Giant after Finding 'Real Harm to Consumers and to Innovation"', The Wall Street Journal, March 19, 2015, http://www. wsj.com/articles/inside-the-u-s-antitrust-probe-of-google-1426793274.

Nazzini, Renato. "Google and the (Ever-stretching) Boundaries of Article 102 TFEU”, Journal of European Competition Law \& Practice 6, 5 (2015): 301-315.

Newman, Nathan. "Search, Antitrust and the Economics of the Control of User Data", Yale Journal on Regulation 31, 2 (2014): 401-454.

Oxera, Benefits of Online Platforms, Report Prepared for Google (2015), http://www. oxera.com/getmedia/84df70f3-8fe0-4ad1-b4ba-d235ee50cb30/The-benefits-ofonline-platforms-main-findings-\%28October-2015\%29.pdf.aspx?ext=.pdf.

Pasquale, Frank. "Paradoxes of Digital Antitrust Why the FTC Failed to Explain Its Inaction on Search Bias", Harvard Journal of Law \& Technology Occasional Paper Series (2013), http://jolt.law.harvard.edu/antitrust/articles/Pasquale.pdf.

Peitz, Martin and Joel Waldfoegel, eds, The Oxford Handbook of The Digital Economy. New York: Oxford University Press, 2012.

Reeves, Amanda P. and Maurice E. Stucke. "Behavioural Antitrust”, Indiana Law Journal 86 (2011): 527-1586.

Rochet, Jean-Charles and Jean Tirole. "Two-Sided Markets: A Progress Report”, The RAND Journal of Economics 37, 3 (2006): 645-667.

Rosch, John Thomas. "Concurring and Dissenting Statement of Commissioner J. Thomas Rosch Regarding Google's Search Practices - In the Matter of Google Inc., dissenting and concurring opinion", in The Matter of Google Inc., FTC File No. 1110163, 3 (January 3, 2012), https://www.ftc.gov/sites/default/files/documents/public_statements/concurring-and-dissenting-statement-commissioner-j.thomas-roschregarding-googles-search-practices/130103googlesearchstmt.pdf.

Rysman, Marc. “The Economics of Two-Sided Markets", Journal of Economic Perspectives 23, 3 (2009): 125-143.

Samuelson, William and Richard Zeckhauser. "Status Quo Bias in Decision Making", Journal of Risk and Uncertainty 1, 1 (1988): 7-59.

Schumpeter, Joseph A. Capitalism, Socialism and Democracy. London: Routledge, 1942. Reprint 1994.

Scotchmer, Suzanne. Innovation and Incentives, Cambridge, Massachusetts: The MIT Press, 2004. 
Shelanski, Howard. "Information, Innovation, and Competition Policy for the Internet", University of Pennsylvania Law Review 161, 1 (2013): 1663-1705.

Sidak, J. Gregory and David J. Teece. "Dynamic Competition in Antitrust Law", Journal of Competition Law and Economics 5, 4 (2009): 581-631.

Stucke, Maurice E. “Behavioural Antitrust and Monopolization”, Journal of Competition Law and Economics 8, 3, (2012): 545-574.

Sullivan, Danny. The Incredible Stupidity of Investigating Google for Acting like a Search Engine (November 30, 2010), http://searchengineland.com/the-incredible-stupidityof-investigating-google-for-acting-like-a-search-engine-57268.

Van Der Vijer, Tjarda. "Objective Justification and Article 102 TFEU”, World Competition 35, 1 (2012): 55-76.

Van Loon, Sophie. "The Power of Google: First Mover Advantage or Abuse of a Dominant Position?", in Empirical Approaches to Legal Aspects of Knowledge-Economy - Business Models, edited by Aurelio Lopez-Tarruella, 22 Information Technology and Law Series, 9-36, The Hague: T. M. C. Asser Press, 2012.

Waller, Spencer Weber and Matthew Sag. "Promoting Innovation", Iowa Law Review, 100 (2015): 2223-2247.

Werden, Gregory J. "Network Effects and Conditions of Entry: Lessons from the Microsoft Case", Antitrust Law Journal 69, 1 (2001): 87-111.

Wiethaus, Lars. "Google's Favouring of Own Services: Comments from an Economic Perspective", Journal of European Competition Law and Practice 6, 7 (2015): 506-512. $\mathrm{Wu}, \mathrm{Tim}$. “Taking Innovation Seriously: Antitrust Enforcement if Innovation Mattered Most", Antitrust Law Journal, 78, 2 (2012): 313-328.

$\mathrm{Wu}$, Tim. The Master Switch. The Rise and Fall of Information Intermediaries. London: Atlantic Books, 2010.

Zimmer, Daniel. "Digital Markets. New Rules for Competition Law”, Journal of Competition Law and Practice, 6, 9 (2015): 627-628. 